\title{
Nebulized racemic epinephrine used in the treatment of severe asthmatic exacerbation: a case report and literature review
}

\author{
Kristopher Wiebe, MD; ${ }^{*}$ Brian H. Rowe, MD, MSc, FCCP ${ }^{\dagger}$
}

\begin{abstract}
Acute asthma is a common emergency department (ED) problem that is typically treated with bronchodilators and anti-inflammatories. Nebulized selective, short-acting $\beta$-agonists, such as salbutamol, are the bronchodilators of choice in most Canadian EDs. Other important treatments in moderate-to-severe cases include systemic corticosteroids and in severe cases may include the addition of ipratropium bromide and magnesium sulfate. Despite aggressive management, some patients do not respond adequately to nebulized salbutamol. Treatment options in these patients are limited to interventions such as parenteral epinephrine, and non-invasive and mechanical ventilation (or both). Both parenteral epinephrine and mechanical ventilation have associated risks, so alternative treatments with a lower risk profile would be useful for the treatment of life-threatening asthma. The following case report describes a patient in whom nebulized racemic epinephrine was used successfully to treat severe acute asthma following failure of standard first-line therapies.
\end{abstract}

Key words: asthma, emergency department, bronchodilators

RÉSUMÉ

L'asthme aigu est un problème courant dans les services d'urgence que l'on traite habituellement au moyen de bronchodilatateurs et d'anti-inflammatoires. Des agonistes bêta à action brève, sélectifs et en aérosol, comme le salbutamol, sont les bronchodilatateurs de choix dans la plupart des services d'urgence du Canada. Les corticostéroïdes systémiques sont au nombre des autres traitements importants dans les cas de gravité moyenne à sévère. Dans les cas graves, on peut ajouter du bromure d'ipratropium et du sulfate de magnésium. En dépit d'une prise en charge agressive, certains patients ne répondent pas adéquatement au salbutamol en aérosol. Les choix de traitement dans ces cas sont limités aux interventions comme l'épinéphrine parentérale et la ventilation non effractive et mécanique (ou les deux). L'épinéphrine parentérale et la ventilation mécanique comportent toutes deux des risques et c'est pourquoi d'autres traitements présentant un profil de risque moins élevé seraient utiles pour traiter l'asthme qui met la vie en danger. Le rapport de cas qui suit décrit un patient chez qui on a utilisé avec succès de l'épinéphrine racémique en aérosol pour traiter une crise d'asthme aigu sévère à la suite de l'échec des thérapies de première intention habituelles.

\section{Introduction}

Acute asthma is a common emergency department (ED) problem in North American that can occasionally present with severe respiratory distress and may require intubation. There are several clinical practice guidelines that describe the management of acute asthma. ${ }^{1,2}$ Most recommend inhaled salbutamol (albuterol) as the mainstay of ED bron-

From the *Department of Emergency Medicine, Chilliwack General Hospital, Chilliwack, BC and the tDepartment of Emergency Medicine, University of Alberta, Edmonton, Alta.

Received: Dec. 4, 2006; revisions received: Feb. 27, 2007; accepted: Mar. 19, 2007

This article has been peer reviewed.

Can J Emerg Med 2007;9(4):304-8 
codilator treatments. ${ }^{3,4}$ Other first-line treatments for severe acute asthma include nebulized ipratropium bromide ${ }^{5}$ as well as systemic ${ }^{6}$ and inhaled corticosteroids. ${ }^{7}$ Second-line treatments for severe and life-threatening asthma include intravenous (IV) magnesium sulfate, ${ }^{8}$ heliox ${ }^{9}$ and parenteral epinephrine. ${ }^{10}$ Finally, when indicated, respiratory support through non-invasive ventilation ${ }^{11}$ or endotracheal intubation can be considered.

Standard first-line therapies suffice for most patients, with only the rare patient requiring intubation..$^{12}$ Nonetheless, there are patients whose presentations are so severe that they fail to respond to standard therapy. For these patients, alternatives are limited. One such alternative is nebulized racemic epinephrine, which has commonly been used in the ED to treat upper airway inflammation such as croup ${ }^{13}$ and lower airway inflammation in bronchiolitis. ${ }^{14}$ However, its role in the treatment of severe acute asthma is unclear. We describe a case in which nebulized racemic epinephrine was used successfully in a patient with severe acute asthma refractory to standard therapy with salbutamol, ipratropium bromide, corticosteroids and magnesium sulfate.

\section{Case report}

A 20-year-old female presented to a community ED with severe shortness of breath. At triage she was noted to be speaking in one word sentences. Her oxygen saturations were $75 \%-80 \%$ on room air. The only history obtainable on presentation was that she had been using her "puffer" with no relief. Limited physical examination revealed severe respiratory distress, with decreased breath sounds bilaterally. Her trachea was midline and her jugular venous pressure was difficult to assess because the patient was obese and had a short neck. She was taken immediately to a resuscitation room and given supplemental oxygen as well as nebulized salbutamol $5 \mathrm{mg}$ and ipratropium bromide $0.5 \mathrm{mg}$. We obtained IV access and established cardio-respiratory monitoring. We ordered a portable chest radiograph (CXR), and made preparations for emergent intubation and mechanical ventilation. All of the above treatments were initiated within 5 minutes of the patient's presentation.

The patient's vital signs revealed a respiratory rate of $40-50$ breaths/minute, a heart rate of 157 beats/minute, blood pressure of 110/50 $\mathrm{mm} \mathrm{Hg}$ and oxygen saturation of $90 \%$ on $10 \mathrm{~L}$ of oxygen via face mask. She was afebrile.

No improvement was noted after the first nebulization of salbutamol and ipratropium bromide. There was no clinical evidence of a tension pneumothorax, so medical management continued, and a second nebulization of each was initiated upon immediate completion of the first treatment, approximately 15-20 minutes after the patient's presentation. We also administered IV magnesium sulfate $(2 \mathrm{~g})$ and methylprednisolone (125 mg).

Collateral history revealed that the patient had been diagnosed with asthma approximately 8 months earlier and had not previously been hospitalized for treatment. Symptoms of a viral upper respiratory infection had appeared the day before her presentation, and on the day of her presentation she had been using her "blue puffer" for shortness of breath about every hour (2-3 puffs hourly 20 puffs in 8 hours). Past medical history was otherwise unremarkable and her only prescribed medication was her "blue puffer".

A portable CXR did not reveal any evidence of pneumothorax or infiltrate. The second nebulization resulted in minimal to no improvement. A third salbutamol-ipratropium bromide nebulization was initiated. About 35 minutes after her presentation, we obtained an arterial blood gas (ABG) sample while the patient was receiving $10 \mathrm{~L}$ of oxygen by face mask; the $\mathrm{ABG}$ revealed a $\mathrm{pH}$ of 7.39 , a $\mathrm{PCO}_{2}$ of $39 \mathrm{~mm} \mathrm{Hg}$, a $\mathrm{PO}_{2}$ of $65 \mathrm{~mm} \mathrm{Hg}$ and an $\mathrm{HCO}_{3}$ of $22 \mathrm{mmoL}$.

Despite the above-mentioned treatments, the patient appeared to be tiring, with ongoing respiratory distress. Due to the potential difficulties with safely establishing a definitive airway in this patient, and because the patient was still maintaining her airway independently, we deferred endotracheal intubation while we made appropriate contingency plans, including difficult airway preparations and soliciting assistance from the on-call anesthetist. Within 2-3 minutes of receiving the third salbutamol-ipratropium bromide nebulization, the patient received $0.5 \mathrm{~mL}$ of racemic epinephrine $2.25 \%$ in $2 \mathrm{~mL}$ saline via nebulizer.

The patient's respiratory status was observed 5 minutes after initiation of nebulized racemic epinephrine. Her oxygen saturations increased to $>95 \%(97 \%-99 \%)$ and her respiratory rate decreased to 26 breaths/minute. The patient was able to speak in full sentences and auscultation of the lung fields revealed good air entry bilaterally.

The patient was transferred to the intensive care unit at another hospital about 2.5 hours after she received racemic epinephrine. She was discharged in good condition 2 days later with a final diagnosis of viral exacerbation of reactive airways disease. Her respiratory status remained stable before and during her transfer. Endotracheal intubation and mechanical ventilatory support were not required during this hospital admission.

\section{Discussion}

Acute life-threatening asthma is a rare condition in Canadian EDs; however, when faced with such patients, emer- 
gency physicians should attempt to maximize their treatments to avoid intubation and its associated complications. IV corticosteroids and magnesium sulfate as well as regular inhalation of salbutamol via nebulizer or metered-dose inhaler, ${ }^{4}$ ipratropium bromide ${ }^{5}$ and corticosteroid agents 6 have been shown to reduce the chances of admission and improve pulmonary functions. Not surprisingly, intubation and intensive care unit admissions for asthma are low in most North American settings. ${ }^{12}$

Nebulized racemic epinephrine has long been considered a first-line treatment for respiratory distress associated with upper airway obstruction, especially childhood croup. ${ }^{13}$ It has also been studied as a first-line treatment for respiratory distress associated with bronchiolitis in infants. ${ }^{14}$ Its mechanisms of action for the reduction of upper airway edema are postulated to include the potent vasoconstrictive effect ( $\alpha 1$ effect), as well as reduced microvascular leakage (hence, decreasing edema), decreased mucous production and increased mucociliary clearance. ${ }^{15}$

Epinephrine is also known as a potent bronchodilator secondary to its $\beta_{2}$-receptor agonist effect, making it a useful agent for the treatment of acute asthma exacerbations. Parenterally administered epinephrine, either IV or subcutaneous, is still used as a first-line agent for the ED treatment of severe asthma at some institutions. ${ }^{10}$ Epinephrine, however, has well-described adverse effects, which may include chest pain, myocardial ischemia, cardiac arrhythmia, severe hypertension and tissue ischemia, particularly when administered intravenously, leading some authors to speculate that the nebulized preparation may be an equipotent but safer method of using epinephrine..$^{10,16,17}$

A search of MEDLINE and PubMed from 1960 to 2005 using the search terms racemic epinephrine, epinephrine and nebulizers, vapourizers and asthma, airway diseases, or bronchial hyper-reactivity revealed several randomized trials comparing nebulized epinephrine (racemic or regular) to nebulized salbutamol in the initial treatment for acute asthma. ${ }^{18-22}$ These studies have all documented increases in pulmonary function and clinical status for nebulized epinephrine that are not statistically different from salbutamol. Side effects were similar between groups receiving either salbutamol or epinephrine, leading several authors to conclude that nebulized epinephrine is as effective and as safe as nebulized salbutamol for the treatment of acute severe asthma. ${ }^{18-20}$ Finally, a meta-analysis of randomized trials comparing nebulized epinephrine and $\beta_{2}{ }^{-}$ agonists in the initial treatment of acute asthma revealed a non-significant improvement in pulmonary function for patients who received epinephrine, compared with those who received $\beta_{2}$-agonists. ${ }^{23}$ It should be noted that, based on our literature search, no clinical trial was identified that studied the effect of nebulized epinephrine in patients who did not improve with initial salbutamol treatment. Finally, other dose-response evidence suggests that while, compared with salbutamol, epinephrine is an effective bronchodilator, its effects are less prolonged. ${ }^{24}$ Table 1 summarizes randomized controlled trails comparing nebulized epinepherine with nebulized salbutamol.

There does not appear to be any difference in efficacy between nebulized L-epinephrine and racemic epinephrine (an equimolar mixture of L- and D-epinephrine) if used in equipotent doses for the treatment of croup. ${ }^{3,25}$ Likewise, Lepinephrine and racemic epinephrine have demonstrated similar results when used for other airway diseases, such as post-extubation stridor. ${ }^{26}$ Although racemic epinephrine was used in this case, primarily because of clinical convenience, it is likely that L-epinephrine would also have been efficacious given its apparent equivalence to racemic epinephrine, as demonstrated in the above studies. This is of particular importance to Canadian clinicians in light of the recent manufacturer's announcement that racemic epinephrine (Vaponephrine) has been discontinued and will no longer be available in Canada. Thus, when nebulized epinephrine is indicated, L-epinephrine will soon be the only option available to Canadian emergency physicians. Dosing equivalencies between L-epinephrine and racemic epinephrine formulations are outlined in Table 2 .

In addition to bronchospasm, airway edema and mucous production are known to be pathophysiologic contributors to acute asthma. It is possible that some patients with severe acute asthma may have a relative predominance of airway edema contributing to their respiratory distress. They may respond better to nebulized epinephrine than to nebulized salbutamol, or they may respond to nebulized epinephrine despite a failure to respond to aggressive $\beta_{2}$ agonist therapy. The patient in this case had been using her own metered dose inhaler salbutamol frequently throughout the course of the day before her presentation, raising the possibility that her $\beta_{2}$-receptors were already maximally stimulated, and that airway edema, rather than bronchospasm, was the principal contributor to her respiratory distress at the time of her presentation. Finally, there is evolving evidence that genetic variation in the $\beta_{2}$-receptor influences bronchodilator response to both short- and long-acting $\beta_{2}$-agonist drugs. ${ }^{27}$ Patients with specific $\beta_{2}$ adrenoreceptors appear to respond less favourably to traditional $\beta_{2}$-agonists; and may also represent a group that may benefit from alternative bronchodilators.

While further studies would be helpful in this field, such evidence is slow to emerge. Nebulized epinephrine 
represents an alternative option for those patients with severe acute asthma who have not responded adequately to maximal $\beta_{2}$-agonist therapy. Like many of the other conditions treated by ED physicians, severe acute asthma is not an entirely homogenous condition. Thus, when initial medical treatments do not provide the intended benefit, other diagnostic possibilities and treatments should be considered.

Table 1. Summary of randomized controlled trials comparing nebulised epinephrine with salbutamol

\begin{tabular}{|c|c|c|c|c|c|}
\hline Study, year & Comparisons & Sample size & Study design & Outcome & Effect measures and results \\
\hline $\begin{array}{l}\text { Abroug et al, } \\
1995\end{array}$ & $\begin{array}{l}\text { Nebulized epinephrine } \\
(2 \mathrm{mg}) \text { v. nebulized } \\
\text { salbutamol }(5 \mathrm{mg}) \text { in } \\
\text { adults with severe } \\
\text { asthma }\end{array}$ & $\begin{array}{l}n=11 \\
\text { (epinephrine); } \\
n=11 \\
\text { (salbutamol) }\end{array}$ & $\begin{array}{l}\text { Prospective, } \\
\text { double-blind } \\
\text { randomized } \\
\text { trial }\end{array}$ & $\begin{array}{l}\text { Primary: } \\
\text { PEF; } \\
\text { secondary: } \\
\text { RR, HR, } \\
\mathrm{PCO}_{2}\end{array}$ & $\begin{array}{l}\text { Equal increase in PEF between } \\
\text { groups; equal decrease in HR, } \\
\mathrm{PCO}_{2} \text { between groups; decrease } \\
\text { in RR greater for salbutamol } \\
\text { group; no difference in SEs. }\end{array}$ \\
\hline $\begin{array}{l}\text { Adoun et al, } \\
2004\end{array}$ & $\begin{array}{l}\text { Nebulized epinephrine } \\
(3 \mathrm{mg}) \mathrm{v} . \text { nebulized } \\
\text { terbutaline }(5 \mathrm{mg}) \text { in } \\
\text { adults with severe } \\
\text { asthma }\end{array}$ & $\begin{array}{l}n=18 \\
\text { (epinephrine); } \\
n=20 \\
\text { (terbutlaine) }\end{array}$ & $\begin{array}{l}\text { Prospective, } \\
\text { double-blind } \\
\text { randomized } \\
\text { cross-over } \\
\text { trial }\end{array}$ & $\begin{array}{l}\text { Primary: } \\
\text { PEF; } \\
\text { secondary: } \\
\mathrm{RR}_{1} \mathrm{PaO}_{2}\end{array}$ & $\begin{array}{l}\text { Equal increase in PEF and } \\
\text { decrease in RR between } \\
\text { groups; } \mathrm{PaO}_{2} \text { increase in } \\
\text { terbutaline group; no } \\
\text { difference in SEs. }\end{array}$ \\
\hline $\begin{array}{l}\text { Coupe et al, } \\
1987\end{array}$ & $\begin{array}{l}\text { Two nebulized } \\
\text { treatments of } \\
\text { epinephrine }(1 \mathrm{mg}) \\
\text { v. nebulized salbu- } \\
\text { tamol ( } 2.5 \mathrm{mg} / \mathrm{neb}) \text { in } \\
\text { patients with severe } \\
\text { asthma }\end{array}$ & $\begin{array}{l}n=10 \\
\text { (epinephrine); } \\
n=8 \\
\text { (salbutamol) }\end{array}$ & $\begin{array}{l}\text { Prospective, } \\
\text { double-blind } \\
\text { randomized } \\
\text { trial }\end{array}$ & $\begin{array}{l}\text { Primary: } \\
\text { unclear; } \\
\text { outcomes: } \\
\text { PEF, HR, } \\
\mathrm{PaO}_{2}\end{array}$ & $\begin{array}{l}\text { Equal increase in } \mathrm{PEF} \text { between } \\
\text { groups; increased } \mathrm{PaO}_{2} \text { in } \\
\text { epinephrine group } \\
\text { v. salbutamol group. }\end{array}$ \\
\hline $\begin{array}{l}\text { Plint et al, } \\
2000\end{array}$ & $\begin{array}{l}\text { Three nebulized } \\
\text { treatments of racemic } \\
\text { epinephrine ( } 0.03 \\
\mathrm{~mL} / \mathrm{kg}) \mathrm{v} \text {. salbutamol } \\
(0.03 \mathrm{~mL} / \mathrm{kg}) \text { in child- } \\
\text { ren (age } 1-17) \text { with } \\
\text { mild-to-moderate } \\
\text { asthma }\end{array}$ & $\begin{array}{l}n=60 \\
\text { (epinephrine); } \\
n=61 \\
\text { (salbutamol) }\end{array}$ & $\begin{array}{l}\text { Prospective, } \\
\text { double-blind } \\
\text { randomized } \\
\text { trial }\end{array}$ & $\begin{array}{l}\text { Primary: } \\
\text { PIS; } \\
\text { secondary: } \\
\text { oxygen } \\
\text { saturation, } \\
\text { LOS, } \\
\text { admission } \\
\text { rate, } \\
\text { relapse } \\
\text { rate }\end{array}$ & $\begin{array}{l}\text { No significant differences } \\
\text { between groups on any of the } \\
\text { outcomes; more minor SE in } \\
\text { epinephrine group (primarily } \\
\text { nasal discharge). }\end{array}$ \\
\hline $\begin{array}{l}\text { Zeggwagh et al, } \\
2002\end{array}$ & $\begin{array}{l}\text { Nebulized epinephrine } \\
(6 \mathrm{mg} / \mathrm{hr} \times 2 \mathrm{hr}) \\
\text { v. nebulized } \\
\text { salbutamol } \\
(10 \mathrm{mg} / \mathrm{hr} \times 2 \mathrm{hr})\end{array}$ & $\begin{array}{l}n=22 \\
\text { (epinephrine); } \\
n=22 \\
\text { (salbutamol) }\end{array}$ & $\begin{array}{l}\text { Prospective } \\
\text { randomized } \\
\text { trial }\end{array}$ & $\begin{array}{l}\text { Primary: } \\
\text { PEF, ABGs, } \\
\text { FEV } \\
\text { secondary: } \\
\text { HR, SBP, } \\
\mathrm{K}^{+}, \mathrm{GlC}\end{array}$ & $\begin{array}{l}\text { Equal increases in PEF between } \\
\text { groups; no difference in FEV } \\
\text { or ABGs; } \\
\text { no difference in SEs. }\end{array}$ \\
\hline
\end{tabular}

$\mathrm{PEF}=$ peak expiratory flow; $\mathrm{RR}=$ respiratory rate; $\mathrm{HR}=$ heart rate; $\mathrm{PCO}_{2}=$ partial pressure on carbon dioxide; $\mathrm{SE}=$ side effects; PaO $\mathrm{O}_{2}=$ arterial oxygen partial pressure; $\mathrm{PIS}=$ Pulmonary Index Score; LOS = length of stay; $\mathrm{ABG}=$ arterial blood gas; $\mathrm{FEV}_{1}=$ forced expiratory volume in 1 second; $\mathrm{SBP}=$ systolic blood pressure; $\mathrm{K}^{+}=$serum potassium; Glc = serum glucose.

Table 2. Comparison of racemic epinephrine and L-epinephrine nebulization doses

\begin{tabular}{|c|c|c|}
\hline Drug, strength & Adult dose & Total epinephrine dose (mg) \\
\hline $\begin{array}{l}\text { Racemic epinephrine } \\
\text { (Vaponephrine), * } 2.25 \%\end{array}$ & $\begin{array}{l}\text { Nebulization: } 0.5 \mathrm{cc} \\
\text { diluted in } 3.5 \mathrm{cc} \mathrm{NS}\end{array}$ & $\begin{array}{l}11.25 \mathrm{mg} \text { racemic epinephrine } \\
(=0.5 \mathrm{cc} @ 22.5 \mathrm{mg} / \mathrm{cc}) ; \\
=5.5 \mathrm{mg} \text { L-epinephrine (most } \\
\text { active) and } 5.5 \mathrm{mg} \text { D-epinephrine } \\
\text { (minimal activity) }\end{array}$ \\
\hline L-epinephrine, 1:1000† & $\begin{array}{l}\text { Nebulization: } 5 \mathrm{cc} \\
\text { undiluted; } \\
\text { IM/SC: } 0.3-0.5 \mathrm{cc}\end{array}$ & 5 mg L-epinephrine \\
\hline
\end{tabular}

NS = normal saline; IM = intramuscular; SC = subcutaneous.

*Discontinued by manufacturer in Canada in January 2007.

$\dagger 1: 1000$ epinephrine is universally available in all emergency departments. It is most commonly used via IM/SC routes for treatment of angioedema or anaphylaxis and can be nebulized undiluted. 


\section{Conclusion}

Nebulized epinephrine may be an effective treatment option for patients with severe acute asthma who have not responded to nebulized salbutamol. Further study should be considered to clarify the role of nebulized epinephrine in those patients who have suspected airway edema, who have failed nebulized short-acting selective $\beta_{2}$-agonists or who have genetic $\beta_{2}$-receptor polymorphism.

Competing interests: Neither Drs. Wiebe nor Rowe has received study funding, speaking fees or other support from any company that produces nebulized epinephrine. Dr. Rowe has received speaking fees, consulting fees and partial study funding from the following respiratory companies: AstraZeneca, GlaxoSmithKline, BoehringerIngelheim and Abbott. Neither author owns stocks nor do they benefit directly from the contents of this manuscript.

\section{References}

1. Lemiere C, Bai T, Balter M, et al. Adult Asthma Consensus Guidelines Update 2003. Can Respir J 2004;11(Suppl A):9A-18A.

2. National Asthma Education P. Expert Panel Report II. Guidelines for the Diagnosis and Management of Asthma. Bethesda, (MD): National Institutes of Health; 1997.

3. Camargo CA Jr., Spooner CH, Rowe BH. Continuous versus intermittent beta-agonists in the treatment of acute asthma. The Cochrane Database of Systematic Reviews 2003;4:CD001115.

4. Cates CJ, Bara A, Crilly JA, et al. Holding chambers versus nebulisers for beta-agonist treatment of acute asthma. The Cochrane Database of Systematic Reviews 2003;2:CD000052.

5. Stoodley RG, Aaron SD, Dales RE. The role of ipratropium bromide in the emergency management of acute asthma exacerbation: A meta-analysis of randomized clinical trials. Ann Emerg Med 1999;34:8-18.

6. Rowe BH, Spooner C, Ducharme FM, et al. Early emergency department treatment of acute asthma with systemic corticosteroids. The Cochrane Database of Systematic Reviews 2001;1:CD002178.

7. Edmonds ML, Camargo CA Jr, Pollack CV Jr, et al. The effectiveness of inhaled corticosteroids in the emergency department treatment of acute asthma: a meta-analysis. Ann Emerg Med 2002;40:145-54.

8. Rowe BH, Bretzlaff JA, Bourdon C, et al. Magnesium sulfate for treating exacerbations of acute asthma in the emergency department. The Cochrane Database of Systematic Reviews 2000;1:CD001490.

9. Carter ER. Heliox for acute severe asthma. Chest 2000;117: 1212-3.

10. Putland M, Kerr D, Kelly AM. Adverse events associated with the administration of intravenous epinephrine in emergency department patients presenting with severe asthma. Ann Emerg Med 2006;47:559-63.

11. Ram FSF, Wellington SR, Rowe BH, et al. Non-invasive positive pressure ventilation for treatment of respiratory failure due to severe acute exacerbations of asthma. The Cochrane Database of Systematic Reviews 2005;1(2):CD004360

12. Weber EJ, Silverman RA, Callaham ML, et al. A prospective multicenter study of factors associated with hospital admission among adults with acute asthma. Am J Med 2002;113:371-8.

13. Ledwith C, Shea L, Mauro R. Safety and efficacy of nebulized racemic epinephrine in conjunction with dexamethasone and mist in the outpatient treatment of croup. Ann Emerg Med 1995; 25:331-5.

14. Menon K, Sutcliffe T, Klassen TP. A randomized trial comparing the efficacy of epinephrine with salbutamol in the treatment of acuet bronchiolitis. J Pediatr 1995;126:1004-7.

15. Prendergast M, Jones JS, Hartman D. Racemic epinephrine in the treatment of laryngotracheitis: can we identify children for outpatient therapy? Am J Emerg Med 1994;12:613-6.

16. Rowe BH, Camargo CA. Emergency department treatment of severe acute asthma. Ann Emerg Med 2006;47:564-6.

17. Shaver K, Adams C, Weiss S. Acute myocardial infarction after administration of low dose epinephrine for anaphylaxis. Can J Emerg Med 2006;8:289-94.

18. Abroug F, Nouira S, Boujdaria R, et al. A controlled trial of nebulized salbutamol and adrenaline in acute severe asthma. Intensive Care Med 1995;21:18-23.

19. Adoun M, Frat JP, Dore P, et al. Comparison of nebulized epinephrine and terbutaline in patients with acute severe asthma: a controlled trial. J Crit Care 2004;19:99-102.

20. Zeggwagh A, Abouqal R, Madani N, et al. Comparative efficiency of nebulized adrenaline and salbutamol in severe acute asthma: A randomized controlled prospective study. Ann Fr Anest Reanim 2002;21:703-9.

21. Plint AC, Osmond MH, Klassen TP. The efficacy of nebulized racemic epinephrine in children with acute asthma: a randomized, double-blind trial. Acad Emerg Med 2000;7:1097-103.

22. Coupe MO, Guly U, Brown E, et al. Nebulised adrenaline in acute severe asthma: a comparison with salbutamol. Eur J Respir Dis 1987;71:227-32.

23. Rodrigo GJ, Nannini LJ. Comparison between nebulized adrenaline and beta- 2 agonists for the treatment of acute asthma: a meta-analysis of randomized trials. Am J Emerg Med 2006; 24:217-22.

24. Elatrous S, Elidrissi H, Trabelsi H, et al. Dose-effect of adrenaline nebulization in asthma: comparative study with salbutamol. Rev Pneumol Clin 1997;53:187-91.

25. Waisman Y, Klein BL, Boenning DA, et al. Prospective randomized double-blind study comparing L-epinephrine and racemic epinephrine aerosols in the treatment of laryngotracheitis (croup). Pediatrics 1992;89:302-6.

26. Nutman J, Brooks LJ, Deakins KM, et al. Racemic versus L-epinephrine aerosol in the treatment of postextubation laryngeal edema: results from a prospective, randomized, doubleblind study. Crit Care Med 1994;22:1591-4.

27. Cho SH, Oh SY, Bahn JW, et al. Association between bronchodilating response to short-acting beta-agonist and nonsynonymous single-nucleotide polymorphisms of beta-adrenoceptor gene. Clin Exp Allergy 2005;35:1162-7.

Correspondence to: Dr. Kris Wiebe, 46022 Bridleridge Cr., Chilliwack BC V2R 5W2; kriswieb@telus.net 